\title{
The Element of Fine Art Context in Multimedia Element in Teaching and Learning Material towards Motivation to Learn
}

\begin{abstract}
: effective learning materials, such as media-based materials could deliver and disseminate messages from various sources in a planned way to create a conducive learning environment. This can make learning process efficient and effective. The main focus of this study is the fine art context which is the main element in the world of art towards motivation to learn among student technical and vocational education (TVET). In the meantime, some students often lack understanding in subjects that require higher understanding. Therefore, the purpose of this research is to know how the fine art context could increase the motivation to learn by incorporating multimedia elements in teaching and learning materials for students in technical and vocational colleges $(C V)$. In this research, the focusing location in the south country. This study was conducted on 273 students in (CV) Kluang, Johor as are a sample in research. It is believed that learning using multimedia is very important and can affect students in motivation and teachers could easily modify the lessons to obtain learning objectives. Moreover, this study focuses on the use of multimedia-based materials for evaluation where the materials are also equipped with a material level grading chart for each student being tested. At this stage, the students were tested based on their understanding after instruction using the materials. It used the quantitative approach and data were collected by distributing survey questionnaires to respondents. The outcome of this study has shown that the inclusion of fine arts context in multimedia affects the motivation to learn among the students.
\end{abstract}

Razali. S. S, Ismail. A
Keywords: fine art context, multimedia element, teaching and learning (T\&L) material, motivation to learn, and technical and vocational education TVET.

\section{INTRODUCTION}

There is a need to study how fine art context in multimedia elements used as teaching and learning material could affect TVET students' motivation to learn. Today's education system has undergone rapid changes as evident through the use of technology-based learning methods introduced [1]. The inclusion of educational technology in teaching and learning could improve the teaching and learning process because it focuses on the essential contents of the topics presented, and at the same time, could save time, energy and expenses. Education development cannot be separated from the ever-increasing globalization of science and technology. The context of fine arts is closely linked to the use of technology while multimedia has been extensively used in different fields including printmaking and furniture design.

Revised Manuscript Received on September 22, 2019

Razali. S. S, Faculty of Technical and Vocational Education, University Tun Hussein Onn Malaysia 86400 Batu Pahat, Johor, Malaysia

Ismail. A, Faculty of Technical and Vocational Education, University Tun Hussein Onn Malaysia 86400 Batu Pahat, Johor, Malaysia

*Corresponding Author, sitisoleha1994.ss@gmail.com,
In this light, the advantages of the use of art in multimedia are closely related to the art context. There are five main fine arts contexts painting, sculpture, architecture, time-based media, and ceramics [2]. This definition originally excludes he applied or decorative arts and the products regarded as crafts. Meanwhile, in contemporary practice, these distinctions and restrictions have become essentially meaningless, as the concept or intention of the artist is given primacy, regardless of the means through which this is expressed. As mentioned, this study focuses on students studying in technical and vocational education (TVET), particularly those studying in vocational colleges $(\mathrm{CV})$ in Malaysia. In this light, this study will focus on human-computer interaction as mentioned in Sara (2014) which argued that while human communication mediates learning, it is less relevant to the use of technology for learning as it is more concerned on human-computer interaction [3]. It is important to determine whether multimedia elements can increase the motivation to learn among CV students. It has been noted that an understanding of multimedia elements is crucial. In this regard, student-centered and psychological perspectives are the most prominent approaches in the use of multimedia elements in teaching and learning. Moreover, it is important to examine students' understanding and motivation to determine how it affects the classroom environment.

\section{BACKground \& Problem Statement}

Innovation and challenges have changed today's education. Such changes include the impact of using fine arts context in multimedia elements in teaching and learning materials towards the motivation to learn among TVET student. The multimedia elements in teaching and learning material have become the primary source to motivate students in TVET schools [4]. The inclusion of multimedia elements has made learning more effective, interesting and fun to students in vocational colleges. Hence, instructors should understand how the use of fine arts context in multimedia elements could motivate students.

The use of teaching and materials with multimedia elements could provide TVET students with the motivation to learn. Failure to motivate students educators need to make changes through methods and techniques in the form of delivery in TVET education in the form of multimedia element. It is a challenge that needs to be addressed and addressed immediately. The burden on students to learn the fine arts context in multimedia is one of the factors that contribute to the failure of students to use multimedia as learning materials to students. 
This was agreed by Jarodzka, (2015) who posited that student's art burdened with conventional learning and the use of multimedia could influence students' attitudes, skills, and commitment to learning [1].

The use of fine art context in multimedia elements in technical and vocational learning materials could enhance students' used to address the lack of diversity in teaching methods, the lack in the use of diverse sources, less attention to weak students and focus on literacy teaching [5]. In this regard, technical and vocational education teaching could be improved through the use of fine arts context in multimedia as it could increase students' motivation to learn. This study was conducted in a vocational college $(\mathrm{CV})$ in the southern state in Malaysia. Data were collected using questionnaires distributed to students in the selected CV to probe students' views on the effectiveness of the use of multimedia elements in teaching and learning materials.

\section{OBJECTIVE}

The research objective is:

1. To determine the level of importance of the fine art context in teaching and learning materials.

2. To determine the level of the inclusion of the fine art context based on the multimedia element in teaching and learning.

3. To determine the effect of the fine art context towards students' motivation to learn.

\section{METHODOLOGY}

This study will be conducted in the technical and vocational schools of the entire university but focusing at all of the college vocational at South such as on vocational colleges of the Negeri Sembilan, Melaka and Johor College in all of the countries have are few colleges vocational in the list of the school technique vocational. The study will be descriptive, where the data are analyzed from the questionnaires distributed to teachers and students as are a sample in my research at the Kluang Johor vocational college. This method is suitable for measuring attitudes, opinions or achievements by any amount of variables and in a natural study [6]. Additionally, this method is used as it is easy to collect effective, economical and practical data where it can save cost, energy and require some time.

The population is a research target group so that research findings can be applied. In this study, the research target population consists of southern state student at vocational college $(\mathrm{CV})$ who have been present to the learning program using multimedia elements. Therefore, the data obtained are considered to represent the data on the whole population. The sample taken was 50 percent of the total population. The population of the study was taken from the first-year students to the final year of study at the college vocational Kluang (CV) of 273 students. The student population in each area of specialization in the first year to the third year in the vocational college school.

The research instrument used in this study is a questionnaire. The questionnaire used in this study is divided into four-part namely, Part A respondent demographic information, Part B perception of the respondents on the effectiveness of the fine art context in multimedia element in motivation to learn in understanding during teaching and learning. It could also be

school of southern, Part C Identify the level of the fine arts context impression in multimedia towards student of technical and vocational education in motivation to learn, and Part D Comment and suggestion for improvement in the learning of fine art context in multimedia element to give are motivated to learn for student technical and vocational school. The questionnaire was compiled using a 5 point Likert scale which consisted of a five-level scale.

\section{DATA ANALYSIS}

To analyze the obtained data, the Statistical Package of Social Science (SPSS) computer version 22.0 was used. Analysis of descriptive types of statistics includes finding of mean, standard deviation and percentages, while analysis of inferential statistic is obtained by using Correlation Pearson. The researcher has made the divisions reliability is determined by the measurement of internal consistency type through statistical test is Alpha Cornbrash test to determine the reliability of each item listed. This method was chosen because researchers use instruments for multiple scaled questions such as the Likers scale, References are based on the value of the correlation and interpretation.

\section{FINDING}

The questionnaire for the researcher has reviewed the item that has been constructed before a pilot study. After that, the researchers have distributed questionnaires, analyzed data and the findings of the study, discussions, conclusions and research proposals. The framework of this study is as Table1. Show the operational framework of the study begins with the first step in identifying the problem statement and formulating the research title. Then the researcher chooses the design and Instrument of the study to be used in the questionnaire. Once the instrument is identified then the items in the questionnaire are constructed based on the question of the research.

Table 1 data analysis table

\begin{tabular}{|l|c|}
\hline \multicolumn{1}{|c|}{ Objective } & Analysis \\
\hline $\begin{array}{l}\text { To determine the use of fine art } \\
\text { contexts in multimedia elements } \\
\text { included in teaching and learning } \\
\text { materials. }\end{array}$ & $\begin{array}{c}\text { Descriptive } \\
\text { statistical methods }\end{array}$ \\
\hline $\begin{array}{l}\text { To determine the effect of the } \\
\text { inclusion of the fine arts context into } \\
\text { the multimedia element in teaching } \\
\text { and materials. }\end{array}$ & $\begin{array}{c}\text { Descriptive } \\
\text { statistical methods }\end{array}$ \\
\hline $\begin{array}{l}\text {. To determine the effect of fine arts } \\
\text { context towards students' motivation } \\
\text { to learn. }\end{array}$ & $\begin{array}{c}\text { Method of person } \\
\text { correction }\end{array}$ \\
\hline
\end{tabular}

For the student questionnaire, the researchers distributed a questionnaire to student specialists in computer and network system at Kluang vocational school (CV), Johor as is a sample in research. This is because this student has characteristics similar to the tested population.

In this research, the analysis shows how the result give post and pra research give the student after using the element multimedia in the fine art context using the correlation Pearson analysis. 
Table 2: correlation Pearson after and before using the element multimedia in fine art context.

\begin{tabular}{|c|l|c|c|}
\hline & & Pra & Post \\
\hline Pra & Pearson correlation & 1 & 0.783 \\
& Sig.(2tailed) & $\cdot$ & 0.000 \\
& N & 30 & 30 \\
\hline Post & Pearson Correlation & 0.783 & 1 \\
& Sig.(2tailed) & 0.000 &. \\
& N & 30 & 30 \\
\hline
\end{tabular}

For a post-test, to element, the multimedia as a learning ingredient $\mathrm{R}=0.783$ and correlation is also significant at $\mathrm{p}<$ 0.05 .

\section{DISCUSION}

The above table shows a multimedia element for learning to channel by basic of context fine art, to have an achievement in learning the fine arts context by using multimedia elements in the classroom. Based on the table above shows that the performance of two-way student development or how the use of multimedia elements is being used and can generate three forms of memory work from students. The multimedia element is the use of a variety of media formats to be presented by students to convey information in a more detailed way.

\begin{tabular}{|c|c|c|c|}
\hline Section & Question section & $\begin{array}{l}\text { Number } \\
\text { of items }\end{array}$ & $\begin{array}{c}\text { Alpha } \\
\text { cronbach }\end{array}$ \\
\hline \multirow[t]{6}{*}{ B } & $\begin{array}{l}\text { Perception of the } \\
\text { respondents on the } \\
\text { effectiveness of the fine } \\
\text { art context in } \\
\text { multimedia element in } \\
\text { motivation to learn in } \\
\text { school of southern. }\end{array}$ & \multirow[t]{6}{*}{5} & \multirow[t]{6}{*}{0.722} \\
\hline & Teks & & \\
\hline & Graphic & & \\
\hline & Video & & \\
\hline & Audio & & \\
\hline & Animation & & \\
\hline \multirow[t]{5}{*}{$\mathrm{C}$} & $\begin{array}{l}\text { Communication level } \\
\text { skill }\end{array}$ & 1 & 0.710 \\
\hline & Thinking level skill & 1 & 0.816 \\
\hline & Information technology & 1 & 0.814 \\
\hline & Time management & 1 & 0.799 \\
\hline & $\begin{array}{l}\text { Multimedia element } \\
\text { towards student }\end{array}$ & 1 & 0.720 \\
\hline
\end{tabular}

Table 3 shows the Alpha Cronbach obtained from pilot studies conducted. The overall analysis shows that alpha Cornbrash obtained from the instrument was 0.722 for the measurement of the perceptions of the respondents on the effectiveness of fine art context in multimedia element learning and vocational college school (CV) in Kluang, Johor. For part $\mathrm{C}$, the level of motivation to learn in $\mathrm{T} \& \mathrm{~L}$ teaching and learning has been divided into five divisions is 0.710 for communication level skill, 0.816 for thinking level skills, while for information technology level for students is 0.814 , 0.799 for level of time management and finally, the level of multimedia element towards student 0.720 . The alpha index value of 0.7 or above is good for one instrument that has ten or more items. Therefore, items that have been built are accepted as a whole and need not be changed.

\section{CONCLUSION}

Overall, after the study was conducted and the findings of the analysis were obtained, the researchers consider that finding has answered all the objective of the study. To recap is to determine the use of fine art contexts in multimedia elements included in teaching and learning materials. Of fine arts context in multimedia elements in the teaching and learning materials for TVET education and how it affects the motivation of CV students in the southern state in Malaysia. List of location is Negeri Sembilan, Melaka, and Johor. To ensure that the research is conducted by the objectives and objectives set out, several aspects of the study have been identified. This study focuses only on the impact of fine art contests in multimedia as well as on the role of multimedia elements in increasing the motivation among students in vocational colleges.

Next, the second objective is to determine the effect of the inclusion of the fine arts context into the multimedia element in teaching and materials. , the research obtained can help students assess their own potential before venturing into the multimedia field. In this regard, students need to take the opportunity to venture into the field of multimedia as this field is important in the industry in Malaysia today. It not only motivates students but also contributes to the development of the nation. Besides, this study also helps to open the minds of students that specialization and expertise acquired in a field during study sometimes guarantees a person to gain success. It also gives students the realization that the area of expertise they learn have high levels of multimedia advancement for commercialization.

Finally, the third objective is to determine the effect of fine arts context towards students' motivation to learn. The motivation is a factor that changes an individual's will to achieve his/her goal with the emergence of feelings and reactions. Motivation will lead to the occurrence of a change in the energy in humans where it will touch one's heart by raising the question. Feelings and emotions for learning will act to understand the learning they want to be delivered.

\section{REFERENCES}

[1] Kirschner, Park B, Malone, \& Jarodzka, H. (2015) towards a cognitive theory of multimedia assessment (CTMMA).Open University of the Netherlands \& Lund University, Sweden.

[2] John Mark Froiland (2013) Parents' Weekly Descriptions of Autonomy Supportive Communication: Promoting Children's Motivation to Learn and Positive Emotions. Springer Science Business Media New York.

[3] Sara McNeil (2014) Visualizing mental models: understanding cognitive change to support teaching and learning of multimedia design and development. Association for Educational Communications and Technology.

[4] Ms. Fui-Theng Leow \& Assoc. Prof. Dr Mai Neo (2014). Interactive multimedia learning: innovating classroom education in a malaysia university. The Turkish Online Journal of Educational Technology.

[5] Babette Park, Terri Flowerday \& Roland Brünken (2015). Cognitive and affective effects of seductive details in multimedia learning. University of New Mexico, Educational Psychology.

[6] Daniel Anderson,(2008). The Low Bridge to High Benefits: Entry-Level Multimedia, Literacies, and Motivation: Department of English and Comparative. University of North Carolina, Chapel Hill, NC 27599, USA

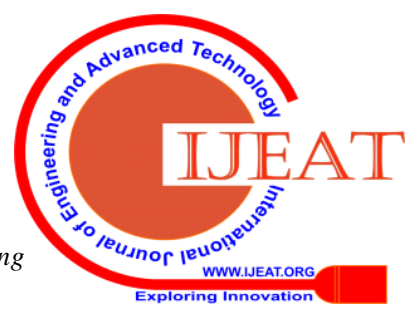




\section{Learn}

[7] Prof. Dr. Mohd \& Elmagzoub A. Babiker (2015) For Effective Use of Multimedia in Education, Teachers Must Develop their Own Educational Multimedia Applications. Ajman University of Science \& Technology.

\section{Authors ProfiLe}

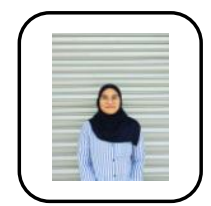

Siti Soleha Binti Razali, Master, as a student master of technical and vocational education, University Tun Hussein Onn Malaysia. She graduated degree in Bachelor of fine art from University of technology MARA (UiTM) at 2018 and the current research interests include multimedia based collaborative in teaching and learning TVET.

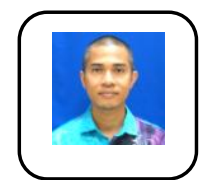

Ts. Dr Affero Bin Ismail $\mathrm{PhD}$, is a lecturer at faculty Technical and Vocational Education, University Tun Hussein Onn Malaysia. He graduated her doctorate degree in technical and vocational education, University Tun Hussein Onn Malaysia 2016. He is Senior Researcher Institution integration engineering, Pusat kecemerlangan Technical and Vocational Education Training (TVET) 2017-2022. Her current research interests include curriculum development and TVET. 